This is the author's final, peer-reviewed manuscript as accepted for publication. The publisher-formatted version may be available through the publisher's web site or your institution's library.

\title{
WHAT DOES THIS MEAN FOR GRADUATE EDUCATION IN MARRIAGE AND FAMILY THERAPY? COMMENTARY ON “THE DIVIDE BETWEEN 'EVIDENCED-BASED' APPROACHES AND PRACTITIONERS OF TRADITIONAL THEORIES OF FAMILY THERAPY"
}

Sandra M. Stith

\section{How to cite this manuscript}

If you make reference to this version of the manuscript, use the following information:

Stith, S. M. (2014). What Does This Mean for Graduate Education in Marriage and Family Therapy? Commentary on "The Divide Between 'Evidenced-Based' Approaches and Practitioners of Traditional Theories of Family Therapy". Retrieved from http://krex.ksu.edu

\section{Published Version Information}

Citation: Stith, S. M. (2014). What Does This Mean for Graduate Education in Marriage and Family Therapy? Commentary on "The Divide Between 'Evidenced-Based' Approaches and Practitioners of Traditional Theories of Family Therapy". Journal of marital and family therapy, 40(1), 17-19.

Copyright: @ 2013 American Association for Marriage and Family Therapy

Digital Object Identifier (DOI):10.1111/jmft.12047

Publisher's Link: http://onlinelibrary.wiley.com/doi/10.1111/jmft.12047/abstract

This item was retrieved from the K-State Research Exchange (K-REx), the institutional repository of Kansas State University. K-REx is available at http://krex.ksu.edu 
What does this mean for graduate education in marriage and family therapy? Commentary on

"The divide between 'evidenced-based' approaches and practitioners of traditional theories of family therapy"

Stith, S. M. (2014). What does this mean for graduate education in marriage and family therapy? Commentary on "The divide between 'evidenced-based' approaches and practitioners of traditional theories of family therapy", Journal of Marital and Family Therapy, 40, 1, 17-19.

\begin{abstract}
The Dattilio, Piercy, and Davis article is a welcome addition to the conversation focusing on how to bridge the divide in the MFT field between research and practice. The present commentary challenges us to see the divide as an indictment of our training programs resulting from a lack of focus on MFT research. Suggestions for increasing expectations for students to monitor client progress, get involved in research at all levels, and for doctoral students to expect to be able to conduct independent, fundable research in the MFT field when they leave their programs are offered.
\end{abstract}


What does this mean for graduate education in marriage and family therapy? Commentary on

"The divide between 'evidenced-based' approaches and practitioners of traditional theories of family therapy"

Dattilio, Piercy, and Davis (2013) do an excellent job highlighting some of the challenges that practitioners, who are devoted to their own "time and experience-tested clinical practices" (p. 3) face when expected to use empirically supported treatment approaches. In their paper they also offer suggestions for ways researchers can make their work more accessible to practitioners and recommendations for family therapy educators. My commentary focuses on recommendations for family therapy educators. I was a faculty member in Virginia Tech's accredited master's program for 20 years, during which time the MFT faculty received NIMH funding and conducted a randomized control trial. Currently I serve as program director in Kansas State University's MFT program offering both master's and doctoral degrees.

If, as the authors assert, "a large number of contemporary practitioners remain ambivalent about the role of research science and its application to clinical practice" (p. 2), this is a serious indictment of psychotherapy education. If students are leaving our programs without recognizing the importance of measuring the effectiveness of their work, or without recognizing the importance of keeping up with the current research on their areas of specialization, we, as educators, have failed. We recently had a master's graduate from another mental health field who questioned our research team about why we had to ask her clients the same questions in the pre- and post-test. She thought it was redundant. I was appalled that a person could have earned a master's degree and not understand how to measure the effectiveness of her work. I have several suggestions for reducing clinician's "ambivalence about the role of research science and its application to clinical practice." I believe that all students in MFT programs should be 
expected to monitor client progress, participate in research experiences, and that $\mathrm{PhD}$ students should be expected to leave their doctoral programs with clear evidence that they are able to conduct independent MFT-related research.

\section{Progress Monitoring}

I agree with the suggestion offered by Dattilio, Piercy, and Davis (2013) that gathering practice-based evidence is an important way to reduce the divide between researchers and practitioners. In fact, I believe that all students in accredited MFT programs should be expected to monitor client progress and outcome. Measuring client progress and outcome is becoming an important part of standard clinical practice (Kadzin, 2006; Lambert, Whipple, Hawkins, Vermeersch, Nielsen, \& Smart, 2003). Many university programs, including Northwestern University, Texas Tech, East Carolina University, University of Georgia, and Auburn are requiring students to monitor client progress. At Kansas State University we ask all adult clients to complete the Outcome Questionnaire-45.2 (Lambert, Gregersen, \& Burlingame, 2004) and each adolescent to complete the Youth Outcome Questionnaire Self-Report (Wells, Burlingame, \& Rose, 2003) according to a required schedule. In addition, we administer the four-item Couple Satisfaction Index (Funk \& Rogge, 2007) and the four-item Negative Interaction Scale (Stanley, Markman, Whitton, 2002) to couples in treatment. Finally, each client is asked to complete the Working Alliance Inventory-Short Form (Horvath \& Greenberg, 1989) according to the same schedule. Students in both programs present graphs of client progress in supervision and they express concern when the alliance is not strong, or when clients do not seem to be making progress. Therapists discuss results with clients, and most therapists find that monitoring client progress and outcome is critical to their ability to assure that they are working effectively. I 
would expect that they will continue to see the value of progress monitoring when they leave the program.

\section{Direct Involvement in Research}

Regardless of whether a student intends to pursue a doctorate or whether a doctoral student intends to seek employment at a research-focused university, our graduates will be more invested in research if they have had research experiences in graduate school. Dattilio, Piercy, and Davis (2013) highlight the importance of MFT faculty being models themselves of using research in their teaching and supervision. I suggest that we should go beyond simply reading and referring to the research conducted by others, but that we should be active producers of research and we should involve students at all levels in the research endeavor. I know that Purdue-Calumet, Brigham Young University, and some other universities require that all master's students complete a research thesis. At Virginia Tech, we only had master's students, but they managed all data collection aspects of a NIMH-funded RCT. They collected qualitative and quantitative data, entered the data, cleaned the data, and made sure that all protocols were followed. We also conducted several large meta-analyses and they conducted searches, coded and cross-coded data, entered data into the meta-analytic software, and ran analyses. I recently spoke with a student who had been involved in that project and he told me that he never read research in the same half-hearted way again after he had to code research articles for the metaanalysis. I have heard faculty members offer as a justification for not getting and managing externally funded research projects the fact that they do not have qualified doctoral students to assist in their work. My own experience is that people often under-estimate the interests and ability of master's students. Currently, each faculty member at KSU has research teams and students are expected to participate on teams, conducting research, and co-authoring posters and 
presentations at conferences, and refereed journal articles. Our students see faculty members taking advanced statistics courses in the summer and working hard to keep up-to-date with the latest research methods and statistical techniques. They hear us talk with passion about our research and are encouraged to work on as many teams as they choose. When we, as faculty members, are passionate about our research projects and about how research informs our clinical work, our passion can inspire our students. If students get involved with coding qualitative interviews, collecting quantitative data, running statistical analyses, and developing grant proposals and papers, they will become more informed and passionate consumers of research, even if they do not choose a research career.

\section{Doctoral Education}

One of the most important factors that can reduce the "divide between 'evidenced-based' approaches and practitioners of traditional theories of family therapy" (Dattilio, Piercy, \& Davis, 2013) would be for doctoral education to have a stronger focus on helping students be able to conduct self-directed research. Doctoral students need to get involved and publish early in their graduate program. The University of Georgia, Kansas State University, and several other universities have reduced (or eliminated) the preliminary examination requirement and instead expect students to complete a portfolio with evidence of publications, conference presentations at national conferences, strong teaching evaluations, and experience reviewing journal articles and conference proposals. Doctoral students are expected to move beyond being a member of a research team to being a leader of a team. If the students graduating from our doctoral programs are not being expected to take cutting edge statistics and research methods courses, to publish, and to get involved with the profession, when they become the next generation of faculty, their students will continue to report "ambivalence about the role of research science and its 
application to clinical practice" (Dattilio, Piercy, \& Davis, 2013, p. 3). Doctoral students who leave our programs prepared to conduct meaningful MFT research will make the difference in our profession remaining viable or fading in comparison to other fields. I am also concerned that many of our faculty and doctoral students are conducting more family science related research, instead of MFT research. Our students should be learning how to develop treatment manuals, conduct efficacy, effectiveness, and dissemination studies to try and keep family therapy on the map of modern health care. Students considering MFT doctoral education need to identify an area of research that they are passionate about, find a faculty mentor and a community of scholars with which to work, and begin to develop as independent scholars. They should consider if their area of passion is also fundable, and if not, they should broaden the area to ensure they can receive funding for their work. As higher education budgets become tighter, the only researchers that are going to thrive are those who have fundable lines of research and those who have the skills and contacts to be able to achieve funding for their work. I am concerned that if our students only study the MFT profession, or if they are not challenged to test the clinical application of theory to their work, they will continue to teach students who do not develop a passion for research and to publish manuscripts that do not inspire clinicians to consider the impact of their research on their clinical work. 


\section{References}

Funk, J. L., \& Rogge, R. D. (2007). Testing the ruler with item response theory: Increasing precision of measurement for relationships satisfaction with the couples satisfaction index. Journal of Family Psychology, 21, 572-583.

Horvath, A. O., \& Greenberg, L. S. (1989). Development and validation of the Working Alliance Inventory. Journal of Counseling Psychology, 36, 223-233.

Kazdin, A. E. (2006). Assessment and evaluation in clinical practice. In C. D. Goodheart, A. E. Kazdin, A. \& R. J. Sternberg (Eds.), Evidence-based psychotherapy: Where practice and research meet (pp. 153-177). Washington, DC: APA.

Lambert, M. J., Gregersen, A. T., \& Burlingame, G. M. (2004). The outcome questionnaire-45. In M. E. Maruish (Ed.), The use of psychological testing for treatment planning and outcome.

Lambert, M. J., Whipple, J. L., Hawkins, E. J., Vermeersch, D. A., Nielsen, S. L., \& Smart, D. W. (2003). Is it time for clinicians to routinely track patient outcome? A meta-analysis. Clinical Psychology: Science and Practice, 10, 288-301.

Stanley, S.M., Markman, H. J., \& Whitton, S. (2002). Communication, conflict, and commitment: Insights on the foundations of relationship success from a national survey. Family Process, 41, 4, 659-675.

Wells, M. G., Burlingame, G. M., \& Rose, P. M. (2003). Youth outcome questionnaire selfreport. American Professional Credentialing Services: Wilmington, DE. 